\title{
KERAGAMAN GENETIK EMPAT POPULASI Intsia bijuga BERDASARKAN PENANDA RAPD DAN IMPLIKASINYA BAGI PROGRAM KONSERVASI GENETIK
}

Genetic Diversity of Four Populations oflntsia bijuga Revealed by RAPD Markers and Its

Implications for The Genetic Conservation Programme

Anto Rimbawanto dan AYPBC Widyatmoko

Pusat Litbang Rutan Tanaman

\begin{abstract}
Intsia bijuga (local name merbau) is a high value timber and has been under intensive utilization. The aim of this study is to investigate genetic variation offour populations to provide information for arranging genetic conservation strategy of the species. Leaves of wildlingfrom four populations were collected and analyzed using 15 RAPD primers which produced 77 polymorphic loci. The average polymorphic locus for each primer was 5.1. The average genetic diversity within population was 0.296 , while between populations was 0.141. Cluster analyses based on population data revealed that the fourpopulations were divided into two groups. The first group consisted ofCarita and Manokwari, while Ternate and Nabire formed another group. Clustering of Manokwari and Nabire into different group support the separation of Papua into 6 geogenetic regions.
\end{abstract}

Key words: Genetic diversity, Intsia bijuga, RAPD

\begin{abstract}
ABSTRAK
Intsia bijuga atau merbau merupakan jenis kayu bemilai ekonomi tinggi dan telah mengalami eksploitasi yang intensif. Penelitian ini bertujuan mempelajari keragaman genetik populasi merbau guna membantu penyusunan strategi konservasi genetik, dengan menggunakan penanda RAPD. Sampel daun dikumpulkan dari 4 populasi dan dianalisa menggunakan 15 primer RAPD yang menghasilkan 77 lokus polimorfik. Rata-rata lokus polimorfik per primer adalah 5.1. Nilai keragaman genetik rerata dalam populasi sebesar 0,296 sedangkan keragaman antara populasi 0.141. Analisis klaster membagi keempat populasi menjadi dua kelompok populasi yaitu Carita dan Manokwari pada kelompok pertama, sedangkan kelompok kedua terdiri dari populasi Temate dan Nabire. Pembagian kelompok antara Manokwari dan Nabire lebih memperjelas pembagian Papua menjadi 6 wilayah geogenetik.
\end{abstract}

Kata Kunci: Intsia bijuga, keragaman genetik, RAPD 


\section{1. $\overline{\text { PENDAHULUAN }}$}

Keragamān genetik diperlükān üntuk mengetahui besarnya variasi genetik yang ada. Besarnya keragaman genetik mencerminkan somber genetik yang diperlukan untük adaptasi ekologi dalām jangka pendek dan evolusi dalam jangka panjang (Lande and Shannon, 1996). Suatu jenis tanaman seharusnya mempunyai dasar keragaman genetik yang cukup untuk dapat beradaptasi dengan perubahan lingkungan.

Penanda molekuler adalah alat yang sangat efektif untuk analisis keragaman genetik tanaman. Salah satu penanda yang banyak digunakan adalah Random Amplified Polymorphic DNA (RAPD) (Welsh and McClelland, 1990; Williams et al., 1990). RAPD adalah penanda berbasis PCR (Polymerase Chain Reaction) dengan menggunakan 10-mer primer random.

I. bijuga (merbau) merupakan salah satu jenis tanaman yang sudah sangat dikenal dalam perdagangan kayu di Indonesia maupun dunia. Di Indonesia jenis ini secara alarni tersebar cukup luas mulai dari Sumatera sampai Papua. Akibat penebangan yang mengabaikan azas kelestarian saat ini populasinya hanya tersisa di Papua dan sebagian Maluku, dan itupun terns menurun kondisinya dari waktu ke waktu. Menurut basil monitoring UNEP-WCMC status konservasi merbau khususnya I. bijuga sudah termasuk katagori Vulnerable A $1 \mathrm{~cd}$ (VUAlcd). Di sisi lain upaya konservasi sebagai langkah penyelamatan merbau dari kelangkaan bahkan kepunahan baik secara in situ maupun ex situ sampai saat ini belum dilaksanakan.

Tujuan dari penelitian ini adalah untuk mengetahui keragaman genetik populasi I. bijuga dalam rangka menyediakan informasi genetik guna penyusunan srategi konservasi jenis ini.

\section{BAHAÑ DAN METODE}

\section{A. Bahan Penelitian}

Bahan penelitian berupa sampel daun dari cabutan di bawah pohon induk merbau yang berasal dari empat populasi, yaitu Kebun Percobaan Carita (Banten), Temate (Maluku), Manokwari dan Nabire. Dari masing-masing pohon induk hanya diwakili oleh satu cabutan, di mana jarak antar pohon induk minimal 100 meter untuk populasi alam. Masing-masing populasi diwakili oleh 24 sampel.

\section{B. Metode Penelitian}

\section{Ekstraksi DNA dan Prosedur RAPD}

Untuk memperoleh totăl DNA dari setiap sampel, daun dari masing-masing individü diekstraksi dengan metode CTAB (Murray and Thompson, 1980) yang telah dimodifikasi (Shiraishi and Watanabe, 1995). Daun seberat $40 \mathrm{mg}$ - $60 \mathrm{mg}$ dihancurkan dalam larutan ekstraksi dengan menggunakan mesin penghancur MiniBead Beater-8 (BioSpec) selama 5 menit dan diinkubasi selama 1 jam dalam suhu $65^{\circ} \mathrm{C}$. Hasil ekstraksi dimurnikan (dipurifikasi) menggunakan GeneClean III Kit (Q-biogene). Konsentrasi DNA dikuantifikasi menggunakan GeneQuant (Pharmacia), selanjutnya dilarutkan menjadi $2,5 \mathrm{ng} / \mu 1$ untuk reaksi PCR.

Reaksi PCR dilakukan dengan total volume $10 \mu 1$ volume yang mengandung Ix Buffer $(10 \mathrm{mM}$ Tris- $\mathrm{HCl}$ (pH8.3), $10 \mathrm{mM} \mathrm{KCl}, 3.0 \mathrm{mM} \mathrm{MgCl}$ ), $200 \mathrm{uM}$ tiap dNTP, 0.25 uM primer, 0.5 units/IO ul AmpliTaq DNA polymerase, Stoffel Fragment (Applied Biosystems), 10 ng larutan DNA. Proses PCR diawali dengan denaturasi selama 60 detik pada suhu $94^{\circ} \mathrm{C}$, diikuti dengan 45 siklus yang masingmasing terdiri dari denaturasi selama 30 detik pada suhu $94^{\circ} \mathrm{C}$, annealing (penempelan primer) selama 30 detik pada suhu $37^{\circ} \mathrm{C}$, dan extention (pemanjangan) selama 90 detik pada suhu $72^{\circ} \mathrm{C}$. Proses $\mathrm{PCR}$ 
diakhiri dengan pemanjangan selama 7 menit pada suhu $72^{\circ} \mathrm{C}$. Keseluruhan proses tersebut menggunakan thermocycler GeneAmp 9700 (Applied Biosystems). Hasil amplifikasi PCR dielektroforesis pada $1.0 \%$ gel agarose, $20 \mathrm{X}$ TBE Buffer dan 0.5\% Ethidium Bromide selama \pm 2 jam pada $120 \mathrm{~V}$. Hasil elektroforesis difoto menggunakan Fotodyne Image Analyzer. Jumlah primer RAPD yang digunakan dalam studi ini adalah 15 primer. Nama primer yang digunakan beserta susunan basanya disajikan pada Tabel 1 .

\section{Analisis Data}

Jarak genetik dihitung berdasarkan pengukuran Nei's (Nei, 1978) dengan mempergunakan bantuan program komputer POPGENE 1.32 (Yeh et al.,1999). Dendrogram menggunakan metode UPGMA dibuat menggunakan datajarak genetik tersebut untuk mengetahui hubungan kekerabatan antar individu dan antar populasi.

\section{HASIL DAN PEMBAHASAN}

\section{A. Keragaman Genetik}

Analisis RAPD menggunakan 15 primer terhadap keempat populasi menghasilkan 77 loci polimorfik. Panjang lokus polimorfik berkisar antara $300 \mathrm{bp}$ - $1100 \mathrm{bp}$. Jumlah lokus yang dihasilkan oleh masing-masing primer berkisar antara dua sampai delapan dengan rata-rata 5,1 loci per primer yang disajikan pada Tabel 1 .

Tabel 1. Daftar primer yang digunakan beserta susunan basanya dan jumlah pita polimorfik yang dihasilkan.

\begin{tabular}{|c|c|c|c|}
\hline No. & Primer & $\begin{array}{c}\text { Sekuens } \\
(5-3)\end{array}$ & $\begin{array}{c}\text { Jumlah pita } \\
\text { polimorfik }\end{array}$ \\
\hline 1 & OPD-01 & ACCGCGAAGG & 2 \\
\hline 2 & OPD-03 & GTCGCCATCA & 7 \\
\hline 3 & OPD-20 & ACCCGGTCAC & 7 \\
\hline 4 & OPH-06 & ACGCATCGCA & 3 \\
\hline 5 & OPO-20 & ACACACGCTG & 4 \\
\hline 6 & OPQ-06 & GAGCGCCTTG & 5 \\
\hline 7 & OPQ-07 & CCCCGATGGT & 6 \\
\hline 8 & OPQ-15 & GGGTAACGTG & 6 \\
\hline 9 & OPU-11 & AGACCCAGAG & 8 \\
\hline 10 & OPV-14 & AGATGGGGCC & 4 \\
\hline 11 & OPW-11 & CTGATGCGTG & 7 \\
\hline 12 & OPY-06 & AAGGCTCACC & 6 \\
\hline 13 & OPY-07 & AGAGCCGTCA & 4 \\
\hline 14 & OPY-11 & AGACGATGGG & 4 \\
\hline 15 & OPY-14 & AGTCGCCCTT & 4 \\
\hline \multicolumn{4}{|c}{ Total } \\
\hline
\end{tabular}

Nilai keragaman genetik berdasarkan analisis keragaman genetik Nei $(1972 ; 1973)$ menunjukkan bahwa populasi Carita mempunyai keragaman tertinggi yaitu 0,317 disusul oleh populasi Manokwari $(0,315)$. Populasi Temate mempunyai keragaman genetik yang terkecil $(0,257)$. Rata-rata keragaman genetik di dalam populasi adalah 0,296 yang disajikan pada Tabel 2 .

Besamya nilai rata-ratajarak genetik antar populasi adalah 0,141. Dengan kata lain, sekitar $86 \%$ dari keragaman genetik berada di dalam populasi. Hubungan terdekat diperlihatkan antara populasi 
Ternate dan Nabire, disusul oleh jarak genetik antara Carita dan Manokwari, sedangkan jarak genetik yang terjauh adalah antara populasi Carita dan Ternate.

Tabel 2. Nilai keragaman genetik dalam populasi (diagonal) dan antar populasi (bawah diagonal) Merbau berdasarkan Nei's Gene Diversity (1973) dan Nei's Original Measures of Genetic Distance (1972)

\begin{tabular}{|l|c|c|c|c|}
\hline \multicolumn{1}{|c|}{ Populasi } & Carita & Manokwari & Ternate & Nabire \\
\hline Carita & 0,317 & & & \\
\hline Manokwari & 0,039 & 0,315 & & \\
\hline Ternate & 0,216 & 0,212 & 0,257 & \\
\hline Nabire & 0,176 & 0,168 & 0,032 & 0,294 \\
\hline
\end{tabular}

Rata-rata keragaman genetik dari empat populasi adalah 0,296. Angka ini lebih besar dari pada rata-rata keragaman genetik baik untuk kelompok jenis tropis maupun jenis konifer, yaitu 0,211 dan 0,207 (Hamrick, 1989). Keragaman genetik I. bijuga ini sedikit lebih besar daripada /. palembanica yang dilaporkan oleh Lee et al. (2002) yaitu sebesar 0,242. Besarnya keragaman genetik ini, seeperti yang dilaporkan untuk /. palembanica (Lee et al., 2002), disebabkan oleh sejarah terbentüknya jenis ini dan proses ekologinya, umur yang panjang, sebarān yang luās dan šistem perkāw̄inañ cāmpur. Walaupun kegiatan eksploitasi sudah banyak dilakukan pada jenis ini, tetapi keragaman genetik dari keempat populasi ini masih dapat dikatakan cukup tinggi. Hal ini disebabkan karena pada keempat populasi ini penebangan belum banyak dilakukan. Kebun Percobaan Carita misalnya merupakan kebun koleksi.

Rata-ratajarak genetik antar populasi dari keempat populasi adalah 0,141 jauh lebih besar daripada I. palembanica 0,04 (Lee et al., 2002) dan Shorea leprosula 0,04 (Rimbawanto dan Suharyanto, 2005), tetapi lebih kecil daripada ulin 0,182 (Purnamila Sulistyowati et al., 2005) dan Araucaria cunninghamii 0,194 (Widyatmoko et al., 2005). Besarnya nilai jarak genetik antar populasi disebabkan karena biji jenis ini cukup berat sehingga hanya jatuh dan tumbuh di sekitar pohon induknya. Di sisi lain, diduga berpindahnya biji yang disebabkan oleh air atau binatang tidak terjadi. Dugaan lainnya adalah luasan populasi I. bijuga cukup besar, sehingga perpindahan serbuk sari maupun biji sebagian besar hanya terjadi di dalam area populasi tersebut.

\section{B. Hubungan Kekerabatan Antar Populasi}

Berdasarkanjarak genetik Nei (1972) disusun dendrogram menggunakan metode UPGMA untuk mengklarifíkasi hubungan antar populasi. Hasil dendrogram yang disajikan pâda Gambār 1 menunjukkan hubungan kekerabatan antara empat populasi yang dianalisis. Keempat popülasi terbagi menjadi 2 kelompok, yaitu Carita dan Manokwari pada kelompok pertama, sedangkan kelompok kedua terdiri dari Ternate dan Nabire.

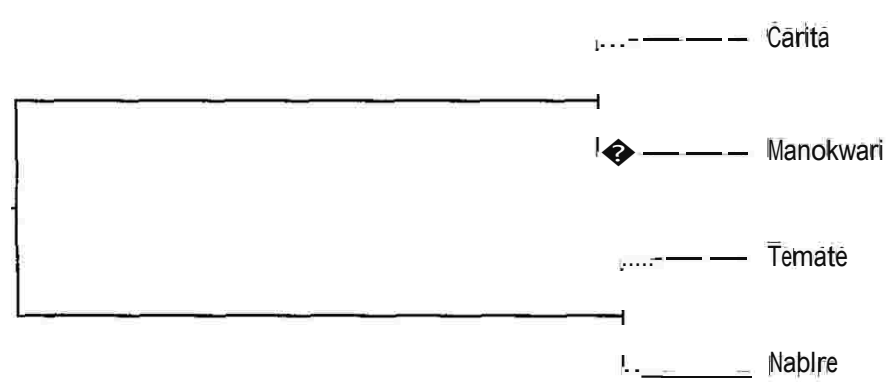

Gambar 1. Dendrogram hubungan kekerabatan antara 4 populasi Merbau berdasarkan jarak genetik Nei's (1972) 
Sepintas pengelompokan yang terjadi seperti tidak berhubungan dengan posisi geografisnya, karena populasi Ternate yang jauh lebih dekat dengan populasi Nabire dibandingkan dengan populasi Manokwari, meskipun secara geografis lebih dekat ke Manokwari, tetaapi apabila dilihăt dari 2 kèlompook yang terbentuk serta jarak genetik antar populasi dalam satu kelompok, pengelompokan yang terjadi terkait dengan pembagian Papua menjadi 6 wilayah berdasarkan pertimbangan geogenetik (Widyatmoko et al., 2005), di mana Manokwari dan Nabire berada pada wilayah yang berbeda.

Populasi Carita mempunyai hubungan kekerabatan yang sangat dekat dengān pooulasi Mānōkwäri karena kemungkinan materi untuk membangun Kebun Percobaan Carita berasal dari Manokwari, tetapi karena ada seleksi individu dalam pengambilan materi genetik maka keragaman genetik Carita sedikit lebih besar dibandingkan dengan Manokwari. Kedekatan hubungan yang samajuga diperlihatkan antara populasi Ternate dan Nabire. Hal ini diduga karena materi genetik di Ternate dahulu dibawa dari Nabire.

Pemahaman tentang keragaman genetik dan hubungan kekerabatan sangat diperlukan baik untuk kegiatan konservasi genetik maupun pemuliaan pohon. Untuk konservasi ex-situ, informasi ini sangat diperlukan untuk menentukanjumlah populasi maüpun individu di dalam populasi yang perlu dikōleksi, sehingga dapat tetap mempertahank:an dasar keragaman genetik yang dimiliki, sedangkan untuk konservasi in-situ, informasi ini diperlukan untuk menentukan jumlah lokasi yang harus ditentukan beserta luasan serta jumlah individu di dalamnya.

Dari kegiatan penelitian ini diperoleh keragaman genetik I. bijuga sebesar 0,296 . Angka íni lebih besar daripada rata-rata keragaman genetik jenis tropis dan konifer. Hal ini menunjukkan bahwa keragaman genetik yang ada di alam masih cukup besar, khususnya untuk mendukung kegiatan pemuliaan. Untuk kegiatan eksplorasi, baik untuk kegiatan pemuliaan maupun konservasi ex-situ, berdasarkan basil yang diperoleh dalam penelitian ini, untuk satu wilayah perlu dikolekși jumlah individu yang cukup banyak dalam satu populasi denganjumlah populasi yang sedikit. Dengan adanya kecenderungan pengelompokan wilayah yang jelas, khususnya di wilayah Papua, maka dari masingmasing wilayah sebaran 7. bijuga di Papua perlu dilakukan koleksi materi seperti di atas. Mengingat jumlah populasi yang digunakan pada penelitian ini masih sedikit (khususnya dari Papua), maka untuk melengkapi informasi keragaman genetik populasi /, bijuga perlu digunakan materi dari populasi yang lain pada sebaran alamnya.

\section{KESIMPULAN}

1. Rata-rata keragaman genetik di dalam populasi dari 4 populasi lntsia bijuga yang digunakan adalah $0,296 \pm 0,028$.

2. Rata-rata jarak genetik antar populasi adalah sebesar $0,141 \pm 0,084$ yang berarti bahwa $86 \%$ keragaman genetik berada di dalam populasi, sedangkan sisanya $14 \%$ berada di antara populasi. Analisis kluster dengan metode UPGMA, membagi empat populasi ke dalam dua kelompok. Kelompok pertama terdiri dari Kebun Percobaan Carita dan Manokwari, sedangkan kélompok yang ke dua terdiri dari Ternate dan Nabire.

4. Untuk tetap menjaga besarnya keragaman genetik dan agar dapat mencakup distribusinya, kegiatan eksplorasi perlu dilakukan di seluruh wilayah sebaran alam I. bijuga, khususnya untuk wilayah Papua.

\section{UCAPAN TERIMA KASIH}

Penulis menyampaikan terima kasih kepada teknisi Wahyunisari dan Y. Triyanta yāng telăh membantu pengambilan sampel di lapangan dan pekerjaan laboratorium. 


\section{DAFTAR PUSTAKA}

Hamrick, J. L. 1989. Isozyme and the analysis of genetic structure in plant population. In Isozyme in Plant Biology. Soltis, D. E. and P. S. Soltis (ed.). Dioscorides Press, Oregon, pp 87-105.

Lande, R. C. and Shannon, S. 1996. The role of genetic variation in adaptation and population persistence in a changing environment. Evolution 50:434-437.

Lee, S-L., Kevin, K.-S., and Saw, L-G 2002. Population genetic of Intsia palembanica (Leguminosae) and genetic conservation of virgin jungle reserves in Peninsular Malaysia. Am. J. Bot. 89:447459 .

Murray, M.G and Thompson, W.F. 1980. Rapid of molecular weight plant DNA. Nuc. Acids. Res. 8. (19): 4321-4325.

NeiM. 1972. Genetic distance between populations. American Naturalist 106: 283-292.

Nei, M, 1973. Analysis of gene diversity in subdivided populations. Proc. Natl. Acad. Sci. USA 70:3321-3323.

Nei, M. 1978. Estimation of average heterozygosity and genetic distance from a small number of individuals. Genetics 89: 583-590.

Purnamila, S., Widyatmoko, A.Y.P.B.C. dan Rimbawanto, A. 2005. Keragaman genetik empat populasi Eusideroxylon zwageri asal Kalimantan berdasarkan penanda RAPD. Prosiding Seminar Nasional Peningkatan Produktivitas Hutan-Peran Konservasi Sumber Daya Genetik, Pemüliaan dan Silvikultur dalam Mendukung Rehabilitasi Hutan, E. B. Hardiyanto (ed.). Fakultas Kehutanan UGM dan ITTO. pp. 383-395.

Rimbawanto, A. dan Suharyanto. 2005. Keragaman genetik populasi Shorea leprosula Miq. dan implifikasinya untuk program konservasi genetik. Prosiding Seminar Nasional Peningkatan Produktivitas Hutan-Peran Konservasi Sumber Daya Genetik, Pemuliaan dan Silvikultur dalam Mendukung Rehabilitasi Hutan, E. B. Hardiyanto (ed.). Fakultas Kehutanan UGM dan ITTO.Yogyakarta. pp. 373-382.

Shiraishi, S and Watanabe, A. 1995. Identification of hloroplast genome between Pinus densiflora SIEB et ZUCC and P. thunbergii PARL. based on the polymorphisms in rbcL gene. J. Jpn. For. Soc. 77:429-436.

Welsh, J. and McClelland, M. 1990. Fingerprinting genome using PCR with arbitrary primers. Nucleic Acid Research 18:7213-7218.

Widyatmoko, AYPBC., Rimbawanto, A. dan Suharyanto. 2005. Keragaman genetik Araucaria cunninghamii menggunakan penanda RAPD. Prosiding Seminar Nasional Peningkatan Produktivitas Hutan-Peran Konservasi Sumber Daya Genetik, Pemuliaan dan Silvikultur dalam Mendukung Rehabilitasi Hutan, E. B. Hardiyanto (ed.). Fakultas Kehutanan UGM dan ITTO.Yogyakarta pp. 397-408.

Williams, J. G. K., Kubelic, A.R., Livak, J. K., Ravalski, J. A. and Tingey, S. V. 1990. DNA polymorphisms amplified by arbitrary primer are useful as genetic marker. Nuc. Acid. Res. (18): 6531-6539p.

Yeh, F.C, Yang, R.C., Boyle, T.B.J., Ye, Z.H. and Mao, J.X. 1999. POPGENE 1.32 The User Friendly Shareware for Population Genetic Analysis. Molecular Biology and Biotechnology Center, University of Alberta, Edmonton. 